\title{
Response of Wheat (Triticum aestivum L.) Plant Grown on Light Textured Soil to Copper Foliar Application Under Different Rates of Nitrogen Fertilization
}

\author{
Abd EL-Aziz M. A.; E. H. Omar; M. M. S. Ragab and M. M. Said ${ }^{1}$
}

\begin{abstract}
A field experiment was conducted at El-Khashaa Balteem, Kafr El-Sheikh Governorate, Egypt during two successive growing seasons $(2005 / 2006$ and $2006 / 2007)$ to investigate the response of wheat (Triticum aestivum L.) variety Sakha 93 to copper application under different levels of nitrogen fertilization grown on copper deficient soil. The experiment was conducted in a split-split plot design with four replicates. Nitrogen fertilization with three $\mathrm{N}$ levels $(80 \%, 100 \%$ and $120 \%$ of the recommended doses: R.D.), the time of $\mathrm{Cu}$ application (tillering stage, early boating stage and two split doses at tillering + early boating stages) and $\mathrm{Cu}$ foliar spray with two levels 0.5 and $1.0 \mathrm{~kg} \mathrm{Cu} /$ fed. are used as the main plot, sub-plot and subsub-plot, respectively. The obtained results showed that wheat grains yield is high significantly increased with increasing the rate of nitrogen application up to $120 \%$ of the recommended dose $(120 \mathrm{~kg} \mathrm{~N} / \mathrm{fed})$ and also with increasing the rate of copper application from 0.5 to $1.0 \mathrm{~kg}$ $\mathrm{Cu} /$ fed. The grains yield was also increased according to the application time of copper as follows: $\mathrm{Cu}$ applied in two split doses at tillering + early boating stages $>\mathrm{Cu}$ applied at early boating stage $>\mathrm{Cu}$ applied at tillering stage. However, the increasing of nitrogen application led to constrain the effect of copper on wheat yield. So that the mean values of the rate of yield increment has decreased with increasing the rate of $\mathrm{N}$ application up to $120 \%$ of the recommended dose with copper application. Application of $120 \% \mathrm{~N}$ of R.D. and $1.0 \mathrm{~kg} \mathrm{Cu} / \mathrm{fed}$, in two split doses at tillering and early boating stages, resulted the highest grain yields, while the lowest grains yield was obtained in the control (zero copper application) at the lowest rate of nitrogen fertilization ( $80 \%$ of R.D.). However application of $100 \% \mathrm{~N}$ of R.D. and $1.0 \mathrm{~kg} \mathrm{Cu} /$ fed in two split doses at tillering and early boating stages was superior than the application of $120 \% \mathrm{~N}$ of $\mathrm{R}$. D without $\mathrm{Cu}$ treatment. The results also showed that wheat straw yield, plant height, spike length and tiller number have the same trend as those of wheat grain yield. Also, N, P, K and protein contents of wheat grains were increased by increasing $N$ levels up to $120 \%$ of $R$. D. It is also clear that $N$ contents of wheat grains were increased with timing of $\mathrm{Cu}$ applications in the order: $\mathrm{Cu}$ applied in two split doses at tillering + early boating stages $>\mathrm{Cu}$ applied at early boating stage $\geq \mathrm{Cu}$ applied at tillering stage, while $P$ and $K$ contents haven't affected by $\mathrm{Cu}$ application time.In the same manner, grains $\mathrm{N}, \mathrm{P}$ and $\mathrm{K}$ uptake followed the same trend as that of $\mathrm{N}, \mathrm{P}$, $K$ and protein contents (\%).
\end{abstract}

\footnotetext{
${ }^{1}$ Soils, Water and Environment Research Institute, A R C.

Received June 6, 2008, Accepted June30, 2008
}

Keywords: Nitrogen, Copper, Application time of copper, Wheat, Protein contents.

\section{INTRODUCTION}

Wheat (Triticum aestivum L.) is the main source for bread as a diet for the Egyptian population and wheat straw is considered as an important animal fodder. The country imported about $60 \%$ of the total consumption of wheat grains. It is important to increase grains of wheat production to reduce this gap. An important technique to increase wheat production is the efficient use of nitrogen fertilization as well as $\mathrm{Cu}$ application.

Nitrogen is most often limiting wheat production. Adequate nitrogen fertilization is necessary to produce high yield and increase its quality (protein content of grains). High levels of protein are important for superior wheat flour milling and baking characteristics. Nitrogen availability plays a key role in determining tiller number, kernel number and kernel size in the wheat plant. Proper wheat fertilization normally have a protein content greater than 14 percent (Franzen and Goos, 1997).

Copper is an essential nutrient required for the normal growth and development of cereal crops. Chlorophyll production, protein synthesis and respiration are important plant functions that need copper. About 70 percent of the copper in plants are found in the chlorophyll. A copper deficiency can result in early aging or lowered levels of chlorophyll, which leads to yield reductions. Copper is necessary for the formation of hemoglobin and also help keep bones, blood vessels, and nerves healthy. Cereal species vary in their sensitivity to copper deficiency. The usual order of sensitivity is: winter wheat> spring wheat> barley> oats $>$ triticale> rye (Solberg et al.,1995).Copper deficiency in cereals produces characteristic symptoms that may be similar for these species. However, crops growing on marginally copper deficient soils may have losses of 20 percent or more in grains yield while not showing visual symptoms of a deficiency. Copper deficiency should be correctly diagnosed before copper fertilizer is applied. The results of a soil test are a much better predictor of the need for $\mathrm{Cu}$ in a fertilizer program (Rehm and Schmitt, 1997). 
On Cu-deficient soils, symptoms generally occur in irregular patches. Deficiency is often first noticed on wheat as "stem melanosis". This is a browning discoloration of wheat associated with reduced yields and ergot infestations (Solberg et al., 1995). In order to correct $\mathrm{Cu}$ deficiency, copper-containing fertilizers have to be applied either to the soil or directly to the plants as foliar spray. Foliar spray is more effective than soil application, particularly under low rainfall condition.Application of high nitrogen levels delays the translocation of copper from older leaves to the growing points (i.e., head development), significantly enhancing copper deficiency. High levels of phosphorous, zinc, iron, manganese and aluminum may also restrict copper absorption by cereal roots (Srivastava and Gupta, 1996). Yield responses to copper application have been thought to be mostly associated with organic soils (Kubota and Alloway, 1972). Canadian research on barley and spring wheat showed yield responses with copper application on mineral soils, mostly with low organic matter content (Karamanos et al., 1986). Because many soils in Egypt fit into this category, the current study aimed to investigate the response of wheat grains grown on light textured soil to copper foliar fertilization under different levels of nitrogen fertilization.

\section{MATERIALS AND METHODS}

\section{Experimental layout}

A field experiment was conducted, at El-Khashaa Balteem, Kafr El-Sheikh Governorate, Egypt during two successive seasons 2005/2006 and 2006/2007. The experimental layout was a split-split plot design with four replicates. The main plot was assigned to $\mathrm{N}$ fertilization with three $\mathrm{N}$ levels: $80 \%, 100 \%$ and $120 \%$ of the recommended dose $(120 \mathrm{~kg} \mathrm{~N} / \mathrm{fed})$, while the subplot was the time of $\mathrm{Cu}$ application (the tillering stage: $T_{1}$, early boating stage: $T_{2}$ and two split doses at tillering + early boating stages: $\mathrm{T}_{3}$ ) and the sub-sub plot was $\mathrm{Cu}$ foliar spray with two levels of applied copper as copper sulfate $\left(\mathrm{CuSO}_{4} .5 \mathrm{H}_{2} \mathrm{O}\right)$ at a rate of 0.5 and 1.0 $\mathrm{kg} / \mathrm{fed}$ as $\mathrm{Cu} 1$ and $\mathrm{Cu} 2$, respectively. The copper treatment contained less than $0.4 \mathrm{Kg} / \mathrm{fed}$. sulfur as a companion ion. Crop responses to applied sulfur are not seen until sulfur rates exceed $4 \mathrm{Kg} / \mathrm{fed}$., It was, therefore, not necessary to include a sulfur application to the check plots. The area of each plot was 5 X 8 square meter.

Wheat grains (Triticum aestivum L.) Sakha 93. at a rate of $60 \mathrm{~kg} / \mathrm{fed}$ were sown. Other agricultural practices were applied according to recommendation of Ministry of Agriculture and Land Reclamation. The grain and straw were collected after maturity from each and their weights were measured at $15 \%$ moisture content. Grain samples were washed by tap water then by distilled water, oven dried at $70^{\circ} \mathrm{C}$ for 48 hours ground in a stainless steel mill and then wet digested according to the method described by Jackson (1967).

Total nitrogen in the digests was determined using the MicroKjeldahl method as described by Jackson (1967). Phosphorus was determined using the calorimetric method (Jackson, 1967). Potassium was determined by using flame photometer (Jackson, 1967).

Soil samples $(0-30 \mathrm{~cm})$ were taken from the experimental site and analyzed before planting. Electrical Conductivity (EC) was determined according to Chapman and Pratt (1961) Soil reaction (pH), total calcium carbonate and organic matter were determined according to Cottenie et al. (1982a). Mechanical analysis was carried out by Pipette method (Piper, 1950). Available phosphorus was extracted using sodium bicarbonate according to Olsen et al. (1954) and then colorimetrically determined using Spectrophotometer (Jackson (1967). Available potassium was determined by using flame photometer in the ammonium acetate extract, (Jackson, 1967). Available copper was determined using Atomic Absorption Spectrometry in the DTPA extract, according to Lindsay and Norvell (1978). The soil analysis data for the experimental site are presented in Table (1). The data obtained were statically analyzed according to Cochran and Cox (1962).

\section{RESULTS AND DISCUSSION}

Table(1) showed that the organic matter content of the soil of the experiment was low $(1.1 \%)$ and the soil is considered copper deficient whereas the level of $\mathrm{Cu}$ in the soil was $0.48 \mathrm{ppm}$ and critical level of soil $\mathrm{Cu}$ deficiency using 0.005 M DTPA (pH 7.3) extractant fall

Table1. Some chemical and physical properties of the soil surface layer $(0-30 \mathrm{~cm})$ before planting

\begin{tabular}{|c|c|c|c|c|c|c|c|c|c|c|c|}
\hline \multirow{2}{*}{$\begin{array}{l}\mathbf{p H}^{*} \\
\mathbf{1}: 2.5\end{array}$} & \multirow{2}{*}{$\begin{array}{c}\mathrm{EC} * * \\
\mathrm{dS} / \mathbf{m} / \mathbf{2 5}{ }^{0} \mathrm{C}\end{array}$} & \multirow[b]{2}{*}{$\underset{\%}{\text { O.M }}$} & \multirow{2}{*}{$\begin{array}{c}\text { Total } \\
\text { Carbonate } \\
\%\end{array}$} & \multicolumn{4}{|c|}{$\begin{array}{c}\text { Available nutrients } \\
\mathrm{mg} / \mathrm{kg}\end{array}$} & \multirow[b]{2}{*}{$\underset{\%}{\text { Clay }}$} & \multirow[b]{2}{*}{$\underset{\%}{\text { Silt }}$} & \multirow[b]{2}{*}{$\underset{\%}{\text { Sand }}$} & \multirow[b]{2}{*}{ Texture } \\
\hline & & & & $\mathbf{N}$ & $\mathbf{P}$ & $\mathbf{K}$ & $\mathbf{C u}$ & & & & \\
\hline 7.9 & 1.85 & 1.1 & 1.54 & 10 & 15 & 518 & 0.48 & 18.3 & 35.8 & 45.9 & $\begin{array}{l}\text { Sandy } \\
\text { loam }\end{array}$ \\
\hline
\end{tabular}

* Measured in $1: 2.5$ soil water suspension, ** Measured in soil saturated water extract. 
in the range of $0.40-0.66 \mathrm{ppm}$ as cited by Karamanos et al. (1986) and Sakal et al. (1984a).

\section{I) Effect of $\mathbf{N}$ fertilization on wheat yield and its components:}

Table(2) showed that the wheat yield and its components: (grains and straw yield, plant height, spike length and tillers number) are high significantly increased with increasing the rate of nitrogen applied up to $120 \%$ of the recommended dose (R.D.) during the two growing seasons. The increment rates of grains yield under $120 \% \mathrm{~N}$ of (R.D.) were $12.95 \%$ and $12.17 \%$ compared to $100 \% \mathrm{~N}$ of (R.D.) in the first and second growing seasons, respectively. However, the corresponding values of the rates of grain yield decrement under $80 \% \mathrm{~N}$ of (R.D.) are $20.80 \%$ and $21.77 \% \%$ compared to $100 \% \mathrm{~N}$ of (R.D.) in the first and second growing seasons, respectively. These result agreed with those obtained by Sabry et al. (1999), ElDesouqi (2000) Muhammad (2001), Maqsood et al. (2002) and Megahed. (2005).

\section{II) Effect of application time of copper:}

Table(2) showed that wheat yield and its components are highly significantly affected by the application time of copper. These are increased in the following order: $\mathrm{Cu}$ applied in two split doses at tillering and early boating stages $>\mathrm{Cu}$ applied at early boating stage $\geq \mathrm{Cu}$ applied at tillering stage, at both the two rates of $\mathrm{Cu}$ application $(0.5,1.0 \mathrm{~kg} \mathrm{Cu} / \mathrm{fed}$.). This points out that the critical period in copper-deficient plants is the early booting stage (Marschner, 1997). These results agree with those reported by Grundon (1980).

\section{III) Effect of copper application on wheat yield and its components:}

Table(2) showed that wheat yield and its components are highly significantly increased as the rate of copper application was increased up to $1 \mathrm{~kg} \mathrm{Cu} / \mathrm{fed}$. This could be attributer to that copper had enhanced chlorophyll synthesis, which led to yield increase (Solberg et al.,1995). The grains yields in the first season increased by 14.58 and $24.94 \%$ as compared with the control (zero $\mathrm{Cu} \mathrm{kg} / \mathrm{fed}$.) for 0.5 and $1.0 \mathrm{~kg} \mathrm{Cu} /$ fed. application, respectively. The corresponding values were $15.95 \%$ and $28.47 \%$ in the second season. These results were agreed with those of Grundon (1980).

IV) Interactions effect between different treatment on wheat grains yield:
Table(3) showed that application of $120 \% \mathrm{~N}$ of R.D. and $1 \mathrm{~kg} \mathrm{Cu} /$ fed. in two split doses at tillering and early boating stages resulted in the highest grains yields $\left(21.31 \& 21.63 \mathrm{ardab} / \mathrm{fed}\right.$. in the $1^{\text {st }}$ and $2^{\text {nd }}$ seasons, respectively). However, the lowest grains yields (11.20 \& $11.05 \mathrm{ardab} / \mathrm{fed}$. for the two seasons, respectively) were obtained in the control (zero cu) and at the lowest rate of nitrogen fertilization ( $80 \%$ of R.D.).

Table(3) illustrates that increasing the rate of nitrogen application led to decrease the stimulating effect of copper application on grains yield. In other words, the mean values of the relative yield increment are decreased with increasing the rate of $\mathrm{N}$ application up to $120 \%$ of R.D. This could be attributed to that, application of high nitrogen levels accentuates $\mathrm{Cu}$ deficiency in plants because of increasing the plant growth increased plant requirements for $\mathrm{Cu}$ (Srivastava and Gupta, 1996). This can be also due to that high application of nitrogen would delay the translocation of copper from older leaves to the growing points (i.e., head development) by promoting the organic $\mathrm{N}$ compound levels in leaves that may bind $\mathrm{Cu}$ and also by delaying senescence of older leaves, which could significantly enhancing copper deficiency (Srivastava and Gupta, 1996).

Table(3) showed that application of $100 \% \mathrm{~N}$ of R.D. and $1 \mathrm{Kg} \mathrm{Cu} / \mathrm{fed}$. in two split doses at tillering and early boating stages was superior to the application of $120 \%$ $\mathrm{N}$ of R.D. without $\mathrm{Cu}$ by about $14.98 \%$ and $16.11 \%$ in the two seasons, respectively.

IV) Effect of $\mathrm{N}$ and $\mathrm{Cu}$ application on $\mathrm{N}, \mathrm{P}, \mathrm{K}$ and protein contents (\%) and $N, P \& K$ uptakes of wheat grains (kg/fed.):

Table(4) showed that N, P, K and protein contents of wheat grains are increased by increasing $\mathrm{N}$ application up to $120 \%$ of R.D. These results agree with those reported by Mohammadi et al. (1991), El-Sherbieny et al. (1999), El-Beyli et al. (2000), Staggenborg et al. (2003) and Megahed (2005). Moreover, N and protein contents are affected by timing of $\mathrm{Cu}$ application where they are increased in the following order: $\mathrm{Cu}$ applied in two split doses at tillering and early boating stages $>\mathrm{Cu}$ applied at early boating stag $\geq \mathrm{Cu}$ applied at tillering stage > $\mathrm{Cu} 0$, within each treatment. However, $\mathrm{P}$ and $\mathrm{K}$ contents were not affected by $\mathrm{Cu}$ time of application. Grains uptake of N, P and K followed the same trend as those of $\mathrm{N}, \mathrm{P}, \mathrm{K}$ and protein contents. 
Table 2. Effect of copper application on wheat yield and its components under different levels of nitrogen fertilization in the two seasons

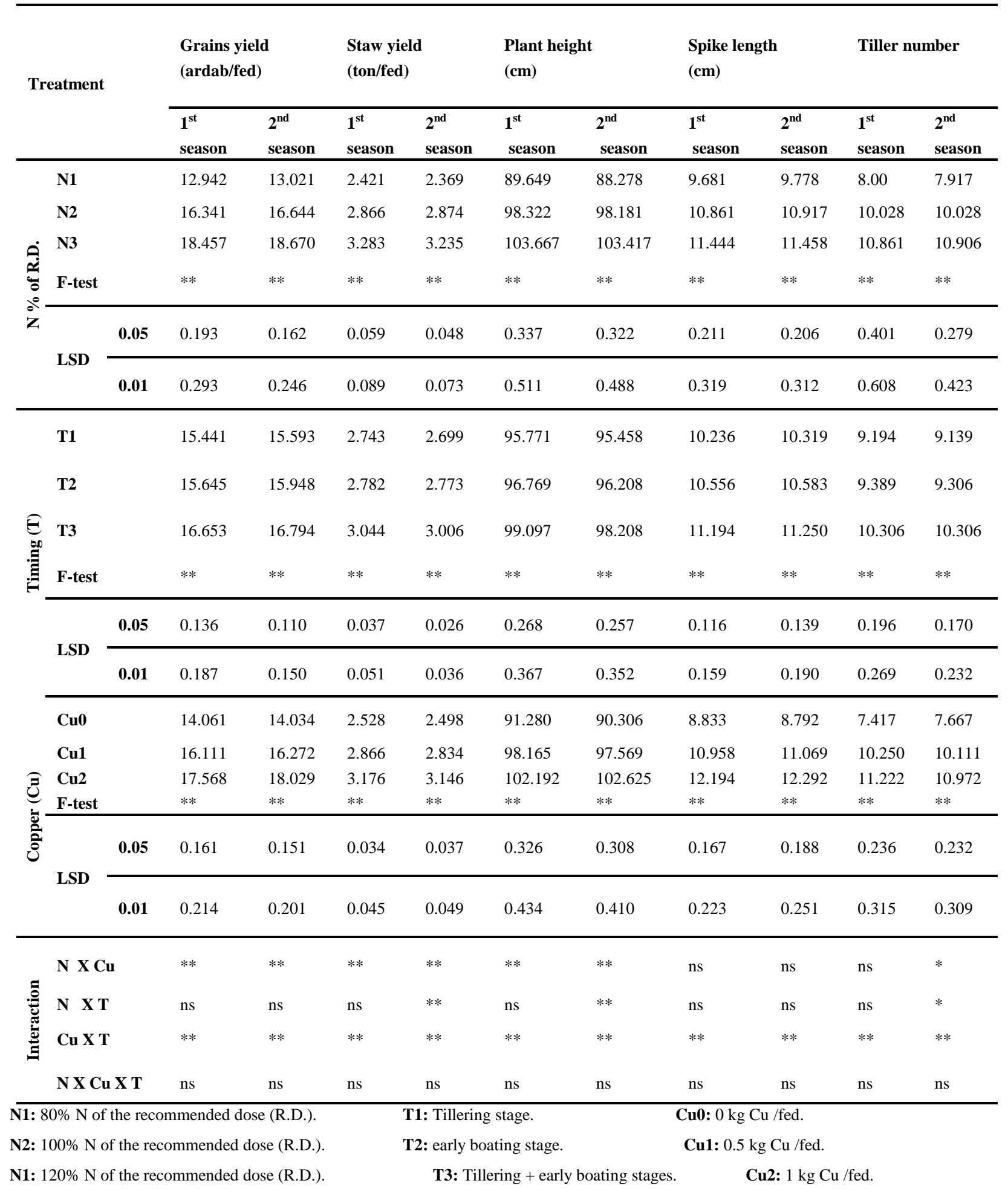


Abd EL-Aziz M. A.; E. H. Omar; M. M. S. Ragab and M. M. Said:Response of Wheat (Triticum Aestivum L.) Plant Grown on Light ......

Table 3. Effect of copper application on wheat grains yield (ardab/fed.) under different levels of nitrogen fertilization (two seasons)

\begin{tabular}{|c|c|c|c|c|c|c|}
\hline \multirow{2}{*}{$\begin{array}{c}\text { N \% of } \\
\text { R.D. }\end{array}$} & \multirow[b]{2}{*}{$\begin{array}{c}\text { Application } \\
\text { time }\end{array}$} & \multirow{2}{*}{$\begin{array}{c}\text { Copper } \\
\text { treatment }\end{array}$} & \multicolumn{2}{|c|}{ First season } & \multicolumn{2}{|c|}{ Second season } \\
\hline & & & $\begin{array}{l}\text { Grains yield } \\
\text { (ardab/fed.) }\end{array}$ & $\begin{array}{c}\text { Relative } \\
\text { increase \% }\end{array}$ & $\begin{array}{c}\text { Grains yield } \\
\text { (ardab/fed.) }\end{array}$ & $\begin{array}{c}\text { Relative } \\
\text { increase \% }\end{array}$ \\
\hline \multirow{8}{*}{$80 \%$} & \multirow{3}{*}{ Tillering } & CuO & 11.20 & 00.00 & 11.05 & 00.00 \\
\hline & & $\mathrm{Cu} 1$ & 12.77 & 14.02 & 12.81 & 15.93 \\
\hline & & $\mathrm{Cu} 2$ & 13.72 & 22.50 & 13.82 & 25.07 \\
\hline & \multirow{2}{*}{$\begin{array}{c}\text { Early } \\
\text { boating }\end{array}$} & $\mathrm{Cu} 1$ & 13.08 & 16.79 & 13.21 & 19.55 \\
\hline & & Cu2 & 13.74 & 22.68 & 14.23 & 28.78 \\
\hline & \multirow{2}{*}{$\begin{array}{c}\text { Tillering+ } \\
\text { early } \\
\text { boating }\end{array}$} & $\mathrm{Cu} 1$ & 14.10 & 25.89 & 14.12 & 27.78 \\
\hline & & $\mathrm{Cu} 2$ & 15.53 & 38.66 & 15.85 & 43.44 \\
\hline & \multicolumn{2}{|c|}{ Mean } & 13.45 & 20.08 & 13.58 & 22.93 \\
\hline \multirow{8}{*}{$100 \%$} & \multirow{3}{*}{ Tillering } & CuO & 14.31 & 00.00 & 14.40 & 00.00 \\
\hline & & $\mathrm{Cu} 1$ & 15.80 & 10.41 & 16.15 & 12.15 \\
\hline & & $\mathrm{Cu} 2$ & 17.47 & 22.08 & 18.08 & 25.56 \\
\hline & \multirow{2}{*}{$\begin{array}{c}\text { Early } \\
\text { boating }\end{array}$} & $\mathrm{Cu} 1$ & 16.06 & 12.23 & 16.34 & 13.47 \\
\hline & & $\mathrm{Cu} 2$ & 17.73 & 23.90 & 18.68 & 29.72 \\
\hline & \multirow{2}{*}{$\begin{array}{c}\text { Tillering+ } \\
\text { early } \\
\text { boating }\end{array}$} & $\mathrm{Cu} 1$ & 17.48 & 22.15 & 17.50 & 21.53 \\
\hline & & $\mathrm{Cu} 2$ & 19.62 & 37.11 & 19.86 & 37.92 \\
\hline & \multicolumn{2}{|c|}{ Mean } & 16.92 & 18.27 & 17.29 & 20.05 \\
\hline \multirow{8}{*}{$120 \%$} & \multirow{3}{*}{ Tillering } & CuO & 16.68 & 00.00 & 16.66 & 00.00 \\
\hline & & $\mathrm{Cu} 1$ & 17.84 & 06.95 & 17.80 & 06.84 \\
\hline & & $\mathrm{Cu} 2$ & 19.19 & 15.05 & 19.58 & 17.53 \\
\hline & \multirow{2}{*}{$\begin{array}{c}\text { Early } \\
\text { boating }\end{array}$} & $\mathrm{Cu} 1$ & 18.22 & 9.23 & 18.43 & 10.62 \\
\hline & & $\mathrm{Cu} 2$ & 19.81 & 18.76 & 20.54 & 23.29 \\
\hline & \multirow{2}{*}{$\begin{array}{c}\text { Tillering+ } \\
\text { early } \\
\text { boating }\end{array}$} & $\mathrm{Cu} 1$ & 19.71 & 18.17 & 20.09 & 20.59 \\
\hline & & $\mathrm{Cu} 2$ & 21.31 & 27.76 & 21.63 & 29.83 \\
\hline & \multicolumn{2}{|c|}{ Mean } & 18.97 & 13.70 & 19.25 & 15.53 \\
\hline
\end{tabular}


Table 4. Effect of copper application under different rates of $N$ application on $N, P$ and $K$ contents and protein content of wheat grains (After the second season)

\begin{tabular}{|c|c|c|c|c|c|c|c|c|c|}
\hline $\begin{array}{c}\text { N \% } \\
\text { of } \\
\text { R.D. }\end{array}$ & $\begin{array}{c}\text { Applicatio } \\
\text { n time }\end{array}$ & $\begin{array}{c}\text { Copper } \\
\text { treatmen } \\
\mathbf{t}\end{array}$ & $\begin{array}{c}\mathrm{N} \\
\text { conten } \\
\mathrm{t} \%\end{array}$ & $\begin{array}{c}\text { Grains } \\
\text { uptake of } \\
\text { N } \\
\text { (kg/fed) }\end{array}$ & $\begin{array}{c}\text { Protei } \\
\text { n } \\
\text { conten } \\
\text { t \% }\end{array}$ & $\begin{array}{c}P \\
\text { conten } \\
\text { t } \%\end{array}$ & $\begin{array}{c}\text { Grains } \\
\text { uptake of } \\
\text { P } \\
\text { (kg/fed) }\end{array}$ & $\begin{array}{c}\mathrm{K} \\
\text { conten } \\
\mathbf{t} \%\end{array}$ & $\begin{array}{c}\text { Grains } \\
\text { uptake of } \\
\text { K } \\
\text { (kg/fed) }\end{array}$ \\
\hline \multirow{8}{*}{$\begin{array}{l}80 \\
\%\end{array}$} & \multirow{3}{*}{ Tillering } & CuO & 1.00 & 16.58 & 6.25 & 0.32 & 5.30 & 0.54 & 8.95 \\
\hline & & $\mathrm{Cu} 1$ & 1.21 & 23.25 & 7.56 & 0.30 & 5.76 & 0.52 & 9.99 \\
\hline & & $\mathrm{Cu} 2$ & 1.26 & 26.12 & 7.88 & 0.31 & 6.43 & 0.42 & 8.71 \\
\hline & Early & Cu1 & 1.22 & 24.17 & 7.63 & 0.31 & 6.14 & 0.50 & 9.91 \\
\hline & boating & $\mathrm{Cu} 2$ & 1.30 & 27.75 & 8.13 & 0.30 & 6.40 & 0.51 & 10.89 \\
\hline & $\begin{array}{c}\text { Tillering+ } \\
\text { early }\end{array}$ & $\mathrm{Cu} 1$ & 1.33 & 28.17 & 8.31 & 0.30 & 6.35 & 0.42 & 8.90 \\
\hline & boating & $\mathrm{Cu} 2$ & 1.36 & 32.33 & 8.50 & 0.31 & 7.37 & 0.49 & 11.65 \\
\hline & \multicolumn{2}{|c|}{ Mean } & 1.24 & 25.48 & 7.75 & 0.31 & 6.25 & 0.49 & 9.86 \\
\hline \multirow{8}{*}{$\begin{array}{c}100 \\
\%\end{array}$} & \multirow{3}{*}{ Tillering } & CuO & 1.39 & 30.02 & 8.69 & 0.38 & 8.21 & 0.63 & 13.61 \\
\hline & & $\mathrm{Cu} 1$ & 1.51 & 36.58 & 9.44 & 0.41 & 9.93 & 0.62 & 15.02 \\
\hline & & $\mathrm{Cu} 2$ & 1.59 & 43.12 & 9.94 & 0.43 & 11.66 & 0.63 & 17.09 \\
\hline & Early & Cu1 & 1.52 & 37.26 & 9.50 & 0.37 & 9.07 & 0.65 & 15.93 \\
\hline & boating & $\mathrm{Cu} 2$ & 1.62 & 45.39 & 10.13 & 0.42 & 11.77 & 0.67 & 18.77 \\
\hline & Tillering+ & Cu1 & 1.62 & 42.53 & 10.13 & 0.40 & 10.50 & 0.66 & 17.33 \\
\hline & $\begin{array}{c}\text { early } \\
\text { boating }\end{array}$ & $\mathrm{Cu} 2$ & 1.81 & 53.92 & 11.31 & 0.40 & 11.92 & 0.67 & 19.96 \\
\hline & Me & & 1.58 & 41.26 & 9.88 & 0.40 & 10.44 & 0.65 & 16.81 \\
\hline \multirow{8}{*}{$\begin{array}{l}120 \\
\%\end{array}$} & & CuO & 1.83 & 45.73 & 11.44 & 0.46 & 11.50 & 0.79 & 19.74 \\
\hline & \multirow{2}{*}{ Tillering } & Cu1 & 1.92 & 51.26 & 12.00 & 0.49 & 13.08 & 0.78 & 20.83 \\
\hline & & $\mathrm{Cu} 2$ & 1.99 & 58.45 & 12.44 & 0.50 & 14.69 & 0.75 & 22.03 \\
\hline & Early & Cu1 & 2.08 & 57.50 & 13.00 & 0.48 & 13.27 & 0.79 & 21.84 \\
\hline & boating & $\mathrm{Cu} 2$ & 2.16 & 66.55 & 13.50 & 0.47 & 14.48 & 0.74 & 22.80 \\
\hline & Tillering+ & Cu1 & 2.31 & 69.61 & 14.44 & 0.47 & 14.16 & 0.83 & 25.01 \\
\hline & $\begin{array}{l}\text { early } \\
\text { boating }\end{array}$ & $\mathrm{Cu} 2$ & 2.37 & 76.89 & 14.81 & 0.49 & 15.90 & 0.88 & 28.55 \\
\hline & \multicolumn{2}{|c|}{ Mean } & 2.09 & 60.86 & 13.09 & 0.48 & 13.87 & 0.79 & 22.97 \\
\hline
\end{tabular}


Abd EL-Aziz M. A.; E. H. Omar; M. M. S. Ragab and M. M. Said:Response of Wheat (Triticum Aestivum L.) Plant Grown on Light ......

\section{CONCLUSION}

Foliar application of $1 \mathrm{~kg} / \mathrm{fed}$. of copper as $\mathrm{CuSO}_{4} .5 \mathrm{H}_{2} \mathrm{O}$ into two split doses, at tillering and early boating stages of wheat plants grown on copper deficient soils increased the over all yield under efficient use of nitrogen fertilization. Also, with foliar application of cupper, the nitrogen application rate could be decreased by about $20 \%$ without significant decrease in grains yield.

\section{RE FERENCES}

Chapman, H. D. and F.Pratt (1961). Methods of Analysis for Soils, Plants and Water. Univ. of Calif., Agric. Dev..

Cochran, W.G. and , G. M. Cox (1960). Experimental Designs, 2nd ed. John Welly, New York, :293-316.

Cottenie, A., Verloo, M., Kikens, L., Veighe, G. and Camerlynck, R., (1982a). Chemical analysis of plants and soils Lab. Anal. And Agrochem. State Univ., Gent. Belgium, Chapter 2, 3 , pp: 14-54.

El-Beyli, U.S., A.I. El-Shafi and A.H. Ahmed (2000). Efficiency of soil and foliar application of potassium fertilizer on yield, yield components and some nutritional constituents of wheat grain on alluvial Bahtim soil. Egypt J. Appl. Sci. 16:297-313.

El-Desouqi, S.A. (2000). Effect of some nitrogen sources on growth and yield of wheat plants. International Colloquium for the Optimization of Plant Nutrients, Yield Quality, The Environment. Cairo (EGY). Apr. 8-13.

El-Sherbieny, A.E., K.G. Soliman and R.M. Ali (1999). Increasing the efficiency of nitrogen fertilizers in newly reclaimed sandy soil. Zagazig J. Agric. Res. 26:38, 895906.

Franzen, D.W. and R.J. Goos (1997). Fertilizing hard red spring wheat, durum, winter wheat and rye. www.ext.nodak.edu/extpubs/plantsci/soilfert/sf712w.htm.

Grundon, N.J. (1980). Effectiveness of soil dressings and foliar sprays of copper sulphate in correcting copper deficiency of wheat (Triticum aestivum L.) in Queensland.Aust. J. Exp. Agric. Anim. Husb. 20: 717723.

Jackson, M.L. (1967). Soil Chemical Analysis. Prentice Hall of India Ltd. New Delhi.

Karamanos, R.E., G.A. Kruger, and J.W.B. Stewart (1986). Copper deficiency in cereal and oilseed crops in northern Canad. Prairie Soils. Agron. J. 78:317-323.

Kubota, J. and W.H. Alloway (1972). Geographic distribution of trace element problems. p 525-554. In: Micronutrients in Agriculture. J.J. Mortvedt et al. (ed.). SSSA, Madison, Wisconsin, USA.
Lindsay, W.L. and W.A. Norvell, (1978). Development of a DTPA soil test for zinc, iron, manganese and copper. Soil Sci. Soc.Am. J. 42: 421-428.

Maqsood, M., A. Ali, A. Zubair, M. Saeed and S. Ahmad (2002). Effect of irrigation and nitrogen levels on grain yield and quality of wheat (Triticum aestivum). Intern. J. Agric. Biology, 4: 164-165.

Marschner, H. (1997). Mineral Nutrition of Higher Plants. Mineral nutrition and yield response. Academic press, London. Pp: 184-200.

Megahed, M.A. (2005). Effect of N-, K- levels, and Timing of application on some Yield components of wheat varieties in the North Middle Delta Region. Thesis, M.sc. Soil Sci. Fac. Agric. Kafer El-Sheikh, Tanta Univ.

Mohammadi, O., L.L. Ristimaki, S. Vermeulen and E. Viikari (1991). Nitrogen fertilization of winter wheat in spring in Finland: comparison of calcium ammonium nitrate and calcium and the effect of split application. J. Agric. Sci. Finland, 63, 93-98.

Muhammad, N.A. (2001). Curve analysis for evaluation of the response of some wheat varieties to different nitrogen fertilization levels. J. Agric. Sci. Mansoura Univ. 24, 1559-1571.

Olsen, S.R., C.V. Cale, F.S. Watenable and L.A. Dean (1954). Estimation of available phosphorus in soil by extraction with sodium bicarbonate U. S. Dep., Agric. Circ., 939.

Piper, C.S. (1950). Soil and Plant Analysis. Inter. Sci. Pub. Inc. New York. USA.

Rehm, G. and M. Schmitt (1997). Copper for crop production. Produced by Communication and Educational Technology Services, University of Minnesota Extension Service. www.extension.umn.edu/distribution/cropsystems/DC679 0.html.

Sabry, S. R. S. ; E. M. Taha and A. A. Khattab (1999). Response of long spike wheat (Triticum aectivum L.) genotypes to nitrogen fertilizer levels in soils of middle Egypt. Bulletin of faculty of Agric., Univ. Cairo. 1999, 50:2, 169-188 ( 20 ref.)

Sakal, R., B.P. Singh and R.B. Sinha (1984a). Evaluation of some chemical extractants for predicting response of wheat grown in pots to copper in sub-Himalayan soils. J. Agric. Sci. (UK) 102: 659-666.

Solberg, E., I. Evans, D. Penny, and D. Maurice. (1995). Copper deficiency in cereal crops. Agri-fax, Agdex 532-2, June, 1995 (revised). Alberta Agriculture, Edmonton, AB.

Srivastava, P.C. and Gupta, U.C. (1996). Trace elements in crop production. Essential trace elements in crop production. Science Publishers, Inc. Lebanon, USA. Pp 73-173.

Staggenborg, S.A., D.A. Whitney and D.L. Fjelland J.P. (2003). Shorter seeding and nitrogen rates required to optimize winter wheat yields fellowing grain sorghum and soybean. Agron. J., 95:2,253-259. 


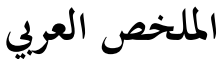

\section{استجابة القمح النامي في ارض خفيفة القوام لإضافة النحاس رشاً تحت معدلات مختلفة}

\section{من التسميد النيتروجيني

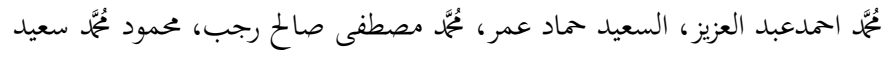

أدت إضافة 120\% من التسميد النيتروجينى الموصى به ورش

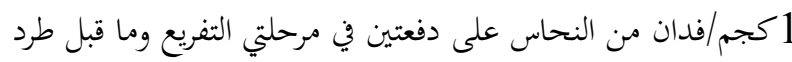

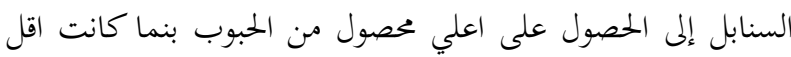
قيمة للمحصول عند إضافة 80\% نيتروجين الموصى به بدون بدون إضافة بهن

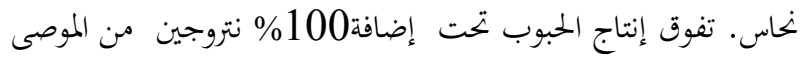
به ورش 1 كجم/فدان من النحاس على دفعتين في مرحلتي التفريع وما

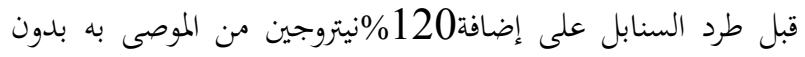

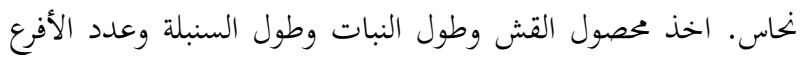

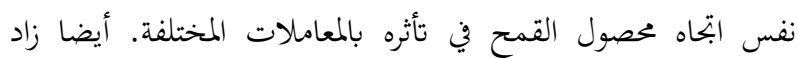
محتوي النبات من النتروجين والفسفور والبوتاسيوم والبروتين زيادة معنوية بزيادة معدلات التسميد النيتروجيني حتى 120\%من ونس الموصي

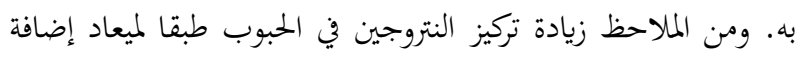
النحاس حسب الترتيب التالي: إضافة عنصر النحاس على دفعتين في مرحلتي التفريع و ما قبل طرد السنابل > مرحلة ما قبل طرد السنابل

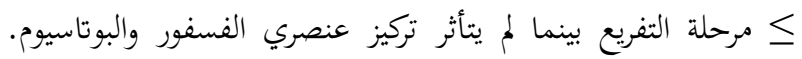
اخذ محتوى النبات من النيتروجين والفوسفور والبوتاسيوم نفس ابتاه تركيز النيتروجين والفوسفور والبوتاسيوم في الحبوب.

الحخلاصة: يمكن الحصول على اعلى انتاج من مصصول الحبوب برش برث

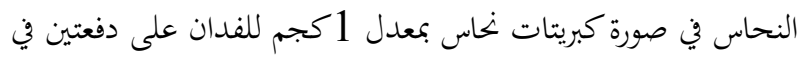
مرحلتي التفريع وما قبل طرد السنابل لنبات القمح المنزرع في تربة خفيفة القوام فقيرة في النحاس مع اضافة الموصى بة من التسميد

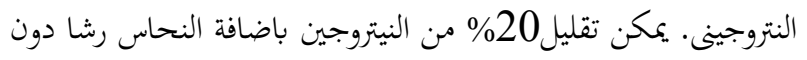

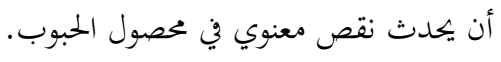

أقيمت بتربة حقلية بمنطقة الخاشعة - بلطيم بمحافظة كفر الشيخ مصر خلال الموسمين الزراعيين 2006/2007- 2005/2006 علي مصول القمح (Triticum aestivum L) صنف سخا 93 لدراسة استجابته للرش بالنحاس تحت مستويات مختلفة من التسميد النيتروجيني. و قد أجريت التجربة باستخدام تصميم القطع المنشقة لئنة ثنائيا في أربع مكررات. وكانت المعاملات المستخدمة هي التسميد

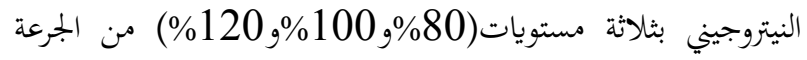
الموصى بها وهى 120 كجم /فدان بالنسبة للأراضي خفيفة القوام), وميعاد رش النحاس في ثلاثة مواعيد (في مرحلة التفريع، مرحلة ما قبل طرد السنابل ثم على دفعتين في مرحلتي التفريع و ما قبل طرد السنابل)

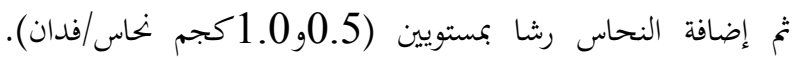
وزعت المعاملات علي القطع الرئيسية والمنشفة والمنشقة ثنائيا علي

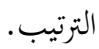
من أهم النتائج المتحصل عليها: زاد محصول الحبوب زيادة معنوية بزيادة معدلات التسميد النيتروجيني حتى 120\% من الموصي به و كذلك بزيادة إضافة النحاس رشا من 0.5 إلى 1 كجم/فدان. أيضا زاد معصول الحبوب لمني زيادة معنوية طبقا لميعاد إضافة النحاس حسب الترتيب التالي التمالي: إضافة عنصر النحاس على دفعتين في مرحلتي التفريع و ما قبل طرد السنابل

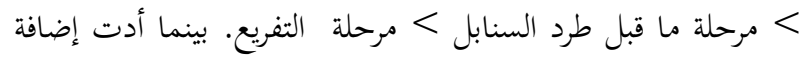

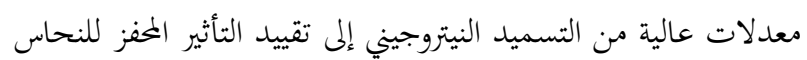
على زيادة المحصول، بمعني أن متوسط قيم معدلات زيات زيادة محصول القمح نتيجة إضافة النحاس كانت أقل عند المستويات العالية من

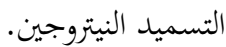

